\title{
Introduction to Value-Relevant and Normative Tradi- tion in Philosophy of the Social Sciences
}

\section{Sosyal Bilimler Felsefesinde Değer-Yüklü ve Normatif Geleneğe Giriș}

\author{
RUHI CAN ALKIN
}

Necmettin Erbakan University

RAMAZAN YELKEN

Selçuk University

Received: 03.I2.I4|Accepted: I4.I2.I4

\begin{abstract}
Methodology, which is one of the most important areas subjected by philosophy of the social sciences, determines the epistemological and ontological position of scientific practice. At this point, the current study proposes to critically analyze positivist epistemology in the social scientific practice while shedding light on the inevitable character of interpretivist methodology for this area. More specifically, study will illustrate the values and normative tradition in specific to research subjects and actors of social sciences. In doing so, study will assert that naturalistic approach, which focuses on cause and effect relations when examining social phenomena, will be shown as an inappropriate tradition in the social sciences in comparison to interpretivist methodology. On the other hand, understanding of "social science for the sake of society" instead of the idea of "social science for the sake of social science" will be examined.
\end{abstract}

Keywords: Philosophy of the social sciences, ontology, epistemology, positivism, interpretivism.

\footnotetext{
\uhi Can Alkın, Arş. Gör.

Necmettin Erbakan Üniversitesi Sosyal ve Beșeri Bilimler Fakültesi Sosyoloji Bölümü 42140, Meram, Konya, TR | ruhicanalkin@gmail.com

$凶$ Ramazan Yelken, Prof. Dr.

Selçuk Üniversitesi Edebiyat Fakültesi Sosyoloji Bölümü $\left.\right|_{4225}$, Meram, Konya, TR ryelken@hotmail.com
} 
"Let us admit then both that a value-free social science is a myth and that social science is governed by a supreme value - the search for truth.”

(Homans, 1978: 54I)

\section{Introduction}

Like many other scientific disciplines, social sciences have both theoretical and methodological backgrounds. Besides dealing with the arguments or specific knowledge regarding any area, social scientists maintain their studies in the light of some methodologies, which help them to reach scientific knowledge in some specific ways. Methodologies, in this respect, could be defined as the techniques that take scientists to their destinations, so-called "scientific theories" or "scientific laws".

In the social sciences, we could easily observe two main methodologies, a) Positivism, which leads social scientists to avoid personal judgments and searching for general scientific assumptions when maintaining a study on social area and b) Interpretivism, which urges social scientists to avoid the tools of natural sciences when dealing with social phenomena and responds personal judgments/values in scientific endeavor normally. This point, which is based on the place of emotions and values in the social sciences, represents the main conflict among two approaches. This current study proposes to take stand with value-relevant approach in the social sciences. In other words, study believes that social scientific endeavor would not be maintained by excluding emotions, values, and special conditions of the researcher, who is the part of the society. In relation to this, study proposes to show the normative character of the social sciences in contrast to illustrative character.

In order to discover the problem given above, firstly, the notions of "ontology" and "epistemology" as one of the core discussions in the philosophy of the social sciences will be issued. Besides describing these notions theoretically, their relationship between main positivistic and interpretivist approaches will be given in the relevant section. After finishing the part on ontology and epistemology, these approaches will be classified in terms of their main features as being empirical or normative. This attempt will probably bring us to the importance of "facts" and "values" and of course priority among them in terms of scientific endeavor. 
Finally, the questions of "can we expect the social sciences to be a normative attempt or should social sciences avoid value judgments and deal only with objective and general correlations between phenomena, which could be defined as "facts"?" will be answered in favour of normative character.

During the study, in order to support the position declared above, discussions regarding both positivist and interpretivist methodologies and also the notions/terms such as normative, empirical, fact, value, valuefree, etc. will be explored in a comparative way.

\section{A Short Touch upon Ontology and Epistemology}

As it is known, there are some core notions and methods in philosophy of the social sciences, which are used by thinkers to support their philosophical positions. Among these notions, ontology could be discussed as one of the beginning points in philosophy. In short, ontology "means study of being-the study of basic building blocks of existence" (Moses \& Knutsen, 2OI2: 4). We could see ontology as large-scaled question seeks "what we study, that is, and objective investigation" and "how the world fits together and how we make sense of it" (Porta \& Keating, 2008: 2I). For a person who would like to engage in scientific endeavor, as you might guess, ontology could be the first step to be taken. In other words, the questions investigate the possibility of "being" refers to ontology. At this point, the second investigation regarding the existing "being" could appear. Epistemology, which is "the side of philosophy that is concerned with questions about knowledge" (Goodfrey-Smith, 2003: 5), come together with the affirmation of the possibility of "being", and of course "knowledge". From this point forth, origins of epistemology could be searched for in the questions of "how to know?" or "how to gain knowledge?" -also- in scientific ways. To correlate the two notions dealt with, a scientist who takes the first step in ontology could pass through epistemological investigation, so it could be asserted that science is an endeavor through which we always observe ontological or/and epistemological claims. Methodology as an inevitable attempt for a scientific endeavor gets on the stage at this point. To remember the definition again, methodology means the "instruments and techniques we use to acquire knowledge" (Porta \& Keating, 2008: 25). In this respect, methodology 
becomes a reference point for the issue of how to gain knowledge, i.e. epistemology.

For a sense, science seems as an effort, which is shaped by methodology that "covers both ontological and epistemological territory" (Moses \& Knutsen, 2012: 5). That is why, it would not be wrong to simply assert that methodology, as a scientific tool, is a way that brings us to "knowledge" in different ways. However, even though methodology covers both ontological and epistemological area, it seems to determine its questions and direction by determining epistemological background of the scientific endeavor. That is why, the main relationship between methodology and two core approaches in the social sciences are better investigated by considering the epistemological examinations rather than ontology.

As they will be detailed in the next part, evaluations on (and preference among) interpretivist and positivist approaches are the consequences of the investigations on epistemology. For example, deciding which technique is useful among "multiple-choice questionnaire" and "semistructured interview" when maintaining a social scientific study on values keeps and declares another decision about the methodology. Obviously, one who prefers to benefit from interviews has already interiorized the interpretivist approach whilst questionnaire is preferred as the declaration of the support to naturalistic approach/methodology. In order to understand the relationship among epistemology and methodologies discussed in this text, the next part will detail and exemplify the two approaches in a more specific way.

\section{Positivist (Naturalist) and Interpretivist (Constructivist) Approaches}

In this part, correlation between methodology and the position of the social sciences (and of course social scientist) in the face of social world will be classified into two approaches, so-called interpretivist and positivist. In combination with this, the notions of value, fact, normative, empirical, etc. will be incorporated in the study. In doing so, it is proposed to introduce to value-free or normative character of scientific endeavor as an epistemological concern.

To start with, positivism exhibits itself in the social sciences since 
they emerged in the $\mathrm{I}^{\text {th }}$ century. Positivism, basically, "assumes that there is a Real World (big R, Big W), out there, independent from our experience of it, and that we can gain access to that World by thinking, observing and recording our experiences carefully" and correlations between phenomena "need to be supported by direct experience" (Moses \& Knutsen, 2OI2: 8) in order to reach to scientific results. This definition shows that positivism, which suggests independency and distinction between subject matter of science and scientist, is an attempt to sustain objective studies, rather than to "undertake rigorous, philosophically informed normative study" (Gerring \& Yesnowitz, 2006: I03). A positivist interpretation in the social sciences, in this respect, directly refers to positivist interpretation on human life. It aims at defining modern people as individuals who get rid of their feelings, expectations, and spiritual life. At least, it is the main target of modernist social science (Rabinow \& Suvillan, 1979).

To sum up, it could be said that positivism is an epistemological response to social scientific endeavor, which is borrowed from the natural sciences. A study that is sustained under the view of positivism expects its implementers to avoid values, personnel judgments. It means that naturalistic approach recognizes scientists as independent pieces from their own social background, environment, and of course society. This expectation and assumption determine another classification among the two approaches discussed so far. Accordingly, epistemological roots of positivism refer to "empirical" background. In other words, positivist scientific endeavor deals with empirical data and "evidences". It may clarify the glorification of the expectations such as value-freed science, objectivity, and generalization in social scientific studies.

Interpretivism, which is another core methodology benefited in the social sciences, has I80 degree contrary position towards positivistic approach. Interpretivism basically discusses that if we deal with human as a biological subject that has some basic necessities and reflexes, of course we can examine him/her in a positivistic way; however, if we take human as a conscious being, we need to consider him/her decisions and activities (Gerring \& Yesnowitz, 2006: 122). Seeing individuals as responsible creatures for their actions brings us to "recognition that people are intelli- 
gent, reflective and willful, and these characteristic matter how we understand the world" (Moses \& Knutsen, 20I2: 8). Importance of human action and its complex structure could be observed here. In addition, unstable and unforeseen feature of human and social processes show that explanations or comments about them might be changeable, i.e. these based on periods and circumstances (Moses \& Knutsen, 20I2). Interpretivist methodology, in this respect, accepts human as a conscious object or as a performer who is recognized in control for his/her actions (Meehan, 1969). This statement reminds the differences between the subjects of social sciences and natural sciences. Accordingly, we have to be aware that we, as humans, are dissimilar from massive things or natural subjects which are handled by natural sciences (Moses \& Knutsen, 2012).

Interpretivism, secondly, re-defines the fulcrum and direction of the social sciences. In interpretivist approach, main attention is paid on the question of "how" instead of "what" (Venesson, 20I2: 233). This direction, which is critically against positivistic approach, provides rich and developed examples of the interpretation of symbols, cultures and historical moments (Rabinow \& Suvillan, 1979). That is why; interpretive approach deals more with specific structure and content of social phenomena (Rabinow \& Suvillan, 1979). At this point, interpretivism goes one step further. Instead of setting up definitions or searching for unavoidable correlations among social phenomena, it tries to understand subjective meanings by focusing the subjective reasons. This could be evaluated as an epistemological shift or development in the social sciences.

Such a point and different perspective in the social sciences bring another idea in scientific endeavor. Accordingly, from the beginning of a research to the main findings, social scientists are not freed from their value judgments, expectations, experiences, etc., so they cannot be expected to avoid these, which could be named "background", when maintaining scientific endeavor. At this point, value-free imagination of the social sciences receives the second blow. Besides the complexity of the research objects (i.e. society, social processes, social structure, etc.), complexity of the "actor" of scientific endeavor weakens the possibility of value-free science. This situation could simply be exemplified by questioning the starting point of a social scientific research, which is "deter- 
mining the subject". It could be said that even determining a specific problem (among hundreds of problems) and then following the necessary steps is based heavily on the position of scientist. As Hesse (1978: 15) states, "[I]f we wish to talk of choice of values it also follows that we presuppose a certain area of freedom in the activity of theorizing". In this respect, determining a problem area for a scientific study is actually "a choice among alternative outcomes, a selection of one outcome in preference to another in a given situation, or the application of set of values to an empirical study" (Meehan, 1959: 28). This could demonstrate the strong link between the social scientific researches and value-relevant approach. Social scientist, in this respect, seems to not even able to start his/her research by ignoring his/her values, expectations, cultural codes and scientific tradition (if any) he/she belongs to.

To better understand (and support) the inevitability of the values in the social sciences, the process of "observation" could be re-examined in terms of its reflections in two methodologies discussed so far. For positivism, observation is the key point for scientific endeavor. Inductivist method, which is one of the key elements of positivism, asserts that starting point of the scientific studies is observation (Gillies, 1993). Especially recurring processes and relationships among social phenomena encourage social scientists to reach generalizations at the end of their researches as a very positivistic manner. Here, observation is pictured as an unintentional and neutral step for scientific studies. After observation, scientist acquires some hypothetical knowledge in terms of his research area. Following steps of research are mainly determined at this point. An interpretivist approach, as you might guess, does not accept such a picture regarding observation. Interpretivism, instead, assumes that observation maintained in (or before) a scientific study cannot be neutral and unintentional. To remember again, scientist's experiences, expectations, status towards his research area or objects, and of course, "values" shape and dominate his/her observations.

For the last point in relation to subjects and actors of the social sciences and the case of "observation", theory-laden recognition of scientific endeavor could be mentioned. To clarify, interpretivist approach reminds that theory does not firstly make itself visible after sets of observations as 
positivism asserts. It has always been, instead: "[E]ven when problems are thought to be specified independently of the theories that are deployed to account for them, in fact they always make implicit reference to some theory (Shapiro, 2002: 60I-602). Embedded structure of theory (and the things and words, etc.) into the everyday life may encourage us to review the possibility of objective observation and absolute recurring correlations in social life.

As you shall see, all of the comparisons among positivist and interpretivist methodologies discussed so far are dependent on the issue of epistemology. Explanations regarding both the objects and actors of social scientific endeavor actually keep the answers to the question of "how to gain knowledge?". It is now obvious that there are some sharp contrasts among two ways to gain knowledge and maintaining social scientific studies. To remember, the main contrast is come into the picture as the status of "values". By incorporating values into the social sciences as interpretivist approach has done so far, target and "reason for being" of the social sciences becomes another problematic. Although positivism urges social scientist to avoid values and takes stand with pure scientific manner, which is based on finding the relationships among social phenomena by some specific techniques, interpretivist approach exceeds the limits of "scientific profession when dealing with the "social". Politics, at this point, becomes an unavoidable process for social scientific endeavor.

\section{Normative Social Science: Science for the Sake of Society}

Unavoidability of values in terms of observation process and choosing a research subject in social scientific studies gives some clues about normative or problem-based position of interpretivism. Instead of dealing only with the relations among social phenomena and/or focusing on "facts", the problem determined by a social scientist ontologically encourages him to engage in normative approach because "[W]hether we like to admit it or not, most social action is normative, implicitly or explicitly" (Winthrop, 1971: 262). In his article, which deeply investigates the facts and principles in the social sciences, Cohen (2003: 2II) explores normative doctrines as defining overall directions that lead social scientists to think "what to do", when fact-based approach emphasizes "what 
is”. To be more precise, Gerring and Yesnowitz's (2006: II2) inspirational sentences could be followed: "Art for art's sake has some plausibility... But no serious person would adopt as her thesis social science for social science's sake. Social science is science for society's sake”. In this analogy, those who take social science for social science's sake seem to represent positivist methodology and those who emphasize society's favors in scientific endeavor seem interpretivist one. Normative base of social science, favor of society, values and other changings in the status of scientific endeavor give us a chance to observe a new relationship between politics and social science.

Basically, normative social science demands that instead of getting stuck in theoretical explanations or pledging loyalty to "cause and effect relation", social science should be interested in demands of the society or keep in touch with policy makers in order to clarify the social phenomena in favour of society or individuals. Even though they might not be capable of suggesting the "best" decision or action to the people who are responsible for policy making, social scientists are able to show at least the basic perspectives regarding the ways that help us to think and interpret the social phenomena (George \& Bennet, 2005). Besides social phenomena, social scientist, "who may differ in important ways in their analyses of challenges and opportunities to be considered in deciding policy" (George \& Bennet, 2005: 273), might assist policy makers. In doing so, another epistemological attempt, which is supposed to keep a philosophy in favor of social, will be practiced. Otherwise, unlike natural sciences that serve humanity by the power of "technique", social sciences would become only intellectual occupations that do not reserve any consideration or responsibility regarding everyday life.

Such a perspective and philosophy for the social sciences, however, brings another problematic, which is based on ethical issues. Interpretivist approach and normative character of science have always been suspected in terms of serving pure political targets and politicians. Later on, such a suspicion could let people to question the role and necessity of the social sciences beside politics. In this respect, social scientists that get over the idea of value-free science and contact partly to politics by their researches or studies need to be careful about involving completely in 
politics. In this particular, for example, "Weber carefully distinguished value-relevance from value-freedom of the social scientist with respect to political action. That is to say, he accepted that judgments of interest select the subject matter of the human sciences, but denied that the social scientist as such should use his theories to argue any political practice" (Hesse, 1978: 9). In doing so, inevitability of the values in scientific studies would not be transformed to pragmatic ideas behind advertisements, political trumps, etc. Thus, reputation of social scientific endeavor and its confidence would not be shaken. On the other hand, this is the best possible way to protect the place of values, which prove (and always remind) the human factor in the social sciences.

\section{Conclusion}

In the light of the arguments discussed so far, it could be observed that positivistic reflections in the social sciences tend to leave a gap among social scientists and their research subjects by suggesting "objectivity". That is to say, according to positivist methodology, "relationship among a biologist and a fish population in a lake" should not demonstrate any slight differences from the "relationship among a sociologist and migrant families in a city" during the scientific processes. This is, actually, the point which is criticized by interpretivists. Such a demand or expectation ignores the reality of human as a social being. On the other hand, such a view searches for generalizations and unchanging/absolute facts regarding social phenomena. After decades when naturalistic approach has been active in the social sciences, it is clear that there is not any absolute fact, which is always valid. Therefore, fact-based and value-free imagination of the social sciences, which tends to avoid personal judgments, does not seem possible to follow. "The idea of a neutral description, free from theoretical or value contamination, is unachievable" (Kratochwil, 2008: 89). This means that social scientific studies, which basically deal with human interactions and also maintained by "humans", would not be practiced in a value-freed way. That is why, epistemological position of a social scientist cannot be considered independently of one of his/her own ontological positions, so-called "social being". This perspective, eventually, supports (or declares) interpretivist methodology in scientific endeavor. 
Besides this new perspective, interpretivist approach brings another ontological and epistemological position in the social sciences. In contrast to neutral descriptions in scientific studies, interpretivist perception is based heavily on the acceptance of politics and value-laden endeavor in the social sciences. It refers to normative texture of the social sciences. Science, in this respect, could be read anymore as a way that seeks for the problems of and solutions for society instead of being an agent that merely focuses on cause and effect relations among social phenomena. Here, ethical issues and the reputation of the social sciences could be a consideration point. In order not to victim the philosophical and intellectual background of the social sciences and not to melt it in pure political targets; social scientist should be careful. As soon as the balance among politics and philosophy is protected, social scientific studies would provide a better understanding and practice for our lives.

\section{References}

Bauböck, R. (2008). Normative Political Theory and Empirical Research. Approaches and Methodologies in the Social Sciences: A Pluralist Perspective (eds. D. D. Porta \&, M. Keating). Cambridge: Cambridge University Press, 40-60.

Cohen, G. A. (2003). Facts and Principles. Philosophy \& Public Affairs, 3I (3), 2II245.

George, A. L. \& Bennet, A. (2005). Case Studies and Theory Development in the Social Sciences. Cambridge: MIT Press.

Gerring, J. \& Yesnowitz, J. (2006). A Normative Turn in Political Science. Polity, 38 (I), IOI-I33.

Goodfrey-Smith, P. (2003). Theory and Reality: An Introduction to the Philosophy of Science, Chicago: The University of Chicago Press.

Gillies, D. (1993). Philosophy of Science in the Twentieth Century: Four Central Themes. Oxford: Blackwell Publishers.

Hesse, M. (1978). Theory and Value in the Social Sciences. Action and Interpretation: Studies in the Philosophy of the Social Sciences (eds. C. Hoowkway \& P. Pettit). Cambridge: Cambridge University Press, I-I6.

Homans, G. (1978). What Kind of a Myth is the Myth of a Value-Free Social Science. Social Science 2uarterly, 58, 530-54I. 
Kratochwil, F. (2008). Constructivism: What It is (Not) and How It Matters. Approaches and Methodologies in the Social Sciences: A Pluralist Perspective (eds. D. D. Porta \&, M. Keating). Cambridge: Cambridge University Press, 80-98.

Meehan, E. J. (1969). Value fudgment and Social Science, Homewood: The Dorsey Press.

Moses, J. W. \& Knutsen, T. (2012). Ways of Knowing: Competing Methodologies in Social and Political Research. Basingstoke: Palgrave Macmillan.

Porta, D. D. \& Keating, M. (2008). How Many Approaches in the Social Sciences? An Epistemological Introduction. Approaches and Methodologies in the Social Sciences: A Pluralist Perspective (eds. D. D. Porta \&, M. Keating). Cambridge: Cambridge University Press, 19-39.

Rabinow, P. \& Suvillan, M. (1979). The Interpretive Turn: Emergence of an Approach. Interpretive Social Science (eds. P. Rabinow, \& M. Suvillan. Berkeley \& Los Angeles: University of California Press, I-2I.

Shapiro, I. (2002). Problems, Methods, and Other Theories in the Study of Politics, or What's Wrong With Political Science and What to Do About It. Political Theory, 30 (4), 596-619.

Venesson, P. (2008). Case Studies and Process Tracing: Theories and Practices. Approaches and Methodologies in the Social Sciences: A Pluralist Perspective (eds. D. D. Porta \&, M. Keating). Cambridge: Cambridge University Press, 223-239.

Winthrop, H. (197I). Some Relations between a Value-Free Sociology and ValueOriented Sociologists. The American Sociologist, 6 (3), 26I-262.

Öz: Sosyal bilimler felsefesinin yoğunlukla üzerinde durduğu alanlardan birisi olan metodoloji, bilimsel pratiğin ontolojik ve epistemolojik pozisyonunu ortaya koyar. Bu çalıșma, sosyal bilimsel pratikteki pozitivist epistemoloji ve metodolojiyi eleștirel olarak analiz etme ve yorumcu geleneğin sosyal bilimler için kaçınılmaz olduğunu gösterme çabasındadır. Diğer bir ifade ile çalıșma, bilimde değer yargılarını ve normatif geleneği sosyal bilimci ve onun araștırma konusu olan toplum/birey özelinde gündeme getirecektir. 
Böylelikle, toplumsalın incelenmesinde salt fenomenler arası neden-sonuç ilișkisine odaklanan natüralist yaklașımın sosyal bilim algısına ters düștüğü de çalıșmanın iddialarından birisi olacaktır. Bu noktada, "sosyal bilim için sosyal bilim" gibi bir anlayıștan ziyade "toplum için sosyal bilim” gibi bir anlayıș da gündeme gelecektir.

Anahtar Kelimeler: Sosyal bilimler felsefesi, ontoloji, epistemoloji, pozitivizm, yorumculuk. 